\title{
DOES FIRM'S HIGHER INNOVATION POTENTIAL LEAD TO ITS SUPERIOR FINANCIAL PERFORMANCE? CASE OF CEE COUNTRIES
}

\author{
Julia BISTROVA ${ }^{\mathrm{a}}$, Natalja LACE ${ }^{\mathrm{b}}$, Rima TAMOŠIŪNIENÉc, \\ Konstatins KOZLOVSKIS ${ }^{\mathrm{d}}$ \\ ${ }^{a, b, d}$ Riga Technical University, Kalnciema 6, LV-1021, Riga Latvia \\ ${ }^{c}$ Vilnius Gediminas Technical University, 11 Sauletekio al., 10223, Vilnius
}

Received 08 April 2016; accepted 25 November 2016

\begin{abstract}
Innovation is one of the most commonly used word in the business and academic world. Naturally the firms are willing to innovate to leverage on future profits and growth generated by the new products and supported by temporary monopolistic positions on the market. However, the question is about how much the companies should invest to record higher profitability. The authors tried to answer this question analyzing the companies within the Central and Eastern European region taking intangible assets as innovation proxy. It was concluded that the companies having higher investments in the intangible assets are able to generate higher margins. However, positive effect of possibly higher innovation potential is seen only if investments in intangibles are substantial, i.e. over $10 \%$.
\end{abstract}

Keywords: innovations, corporate financial performance, profitability, level of intangible assets.

Jel classification: G31, E22, D24.

\section{Introduction}

Innovation may not be considered to be a buzzword anymore. It is so deeply rooted in the business and academic world. Wall Street Journal (Korn 2012) nominated "innovation" as the most overused word in 2012 saying that it was mentioned 33528 times in annual and quarterly reports filed with the Securities and Exchange Commission. Everyone considers it to be a secret source for the corporate results and market value to continue to grow, for the businesses to be competitive (Knott 2012; Griliches 1984; Bilevičienè et al. 2015; Urbaniec 2015), for the economies to develop without limits (Romer 1990; Grossman, Helpman 1994; Jones 1995). Hence, we see billions of euros continue to be invested in the Research and Development (R\&D) activities to bring breakthrough innovations to the market.

Corresponding author Rima Tamošiūnienè

E-mail: rima.tamosiuniene@vgtu.lt 
Based on PriceWaterhouseCoopers (PWC) provided statistics in 2015 (Jaruzelski et al. 2015), the largest R\&D spender in the world is Volkswagen dedicating $\$ 15.3 \mathrm{bn}$, followed by Samsung with $\$ 14.1$ bn and Intel $\$ 11.5$ bn. However, it does not always translate into higher than competitors' growth or margins. For example, the operating profit margin of Samsung was 12\%, while Apple had 28\% in financial years 2014/2015. Volkswagen reported $6 \%$ operating margin, while its closest competitors BMW AG and Daimler AG reported $11 \%$ and $7 \%$ respectively.

Trying to understand the true benefit of the innovations and its influence on the corporate financial ratios, academics and practitioners seem to be in the topic producing a significant number of researches every year. According to the Scopus database, the number of articles having "innovation" as one of the keyword has more than doubled during the last 10 years.

Many researchers argue that innovation potential (as prompted by R\&D spending, amount of intangible assets) positively correlate with the firm's market value and financial performance (Warusawitharana 2008; Artz et al. 2010; Ehie, Olibe 2010). To compare, in a study made by the consulting company Booz Allen in 2006 (Jaruzelski et al. 2006) no evidence of the $\mathrm{R} \& \mathrm{D}$ driving the results (earnings growth, market capitalization growth, total returns) is found.

Neither the influence of patents on the firm's profitability was detected. The only significant relationship discovered was between R\&D spending and gross margin.

Taking into account the contradictory findings recorded in the business and academic research, the authors conducted a study focusing on the innovation potential of the Central and Eastern European (CEE) enterprises. The present research targets to discover the value of innovations for the companies located in the CEE region, which is considered to be less developed, the companies - less innovative and, therefore, less competitive. The authors compared the level of the innovation potential (as proxied in the article by the intangible assets) of the companies operating in less developed Europe to the innovation potential of the companies domiciled in Western Europe and USA. With the help of quantitative analysis the effect of the investments in the intangible assets on the firm's profitability is studied.

The hypothesis prior to the research was stated as follows:

The companies investing in intangible assets more than their peers report higher margins and capital profitability.

The methods chosen for conducting a research are mainly quantitative, which include benchmarking, regression, mean and graphical analysis.

\section{Innovations' value added}

The value added of innovations is being widely researched from different angles: its effect on the shareholder return, profitability, earnings growth, market value; and based on various innovation potential determinants: $\mathrm{R} \& \mathrm{D}$ spending, intangible asset base, $\%$ of sales generated by the new products, number of patents, qualitative assessment of the companies innovativeness. To add, obtained results vary due to the sample specifics (size, region, public/private firms) and, therefore, might be quite different leading to the ambiguous conclusions. 
As stated before, Booz Allen making an annual study (2006) on the innovative companies states that there is no any correlation between the $\mathrm{R} \& \mathrm{D}$ spending and the firm's results observed. Jim Collins and Morten Hansen (2011) emphasizing empirical creativity of the successful firms confirm that more successful companies are rarely more innovative than their less successful companies. It should be noted though that the analyzed sample mainly consisted of the large listed companies and often were admitted to be market leaders.

Harvard Business Review article (Barber, Bistrova 2015) provides an insight into the "R\&D kitchen" of large listed companies indicating that the research primarily happens in the pre-IPO phase, while afterwards it can be outsourced to the private companies mentioning the fact that in the pharmaceuticals industry less that third of CEOs have pharmarelated education and previous career.

Academic research, which more often comes to the conclusion that innovations provide value to the companies, focuses rather on the larger sample including both private and listed companies. Sample specifics can become a partial explanation to the difference on the obtained results.

Kraft and Czarnitzki (2002) researched the influence of the R\&D intensity, stock of patents divided by sales and sales of newly developed products on the developed credit rating, which is closely tracking firms' value. All three measures were found to have significant relationship with the credit rating. Till the certain level of innovativeness the rating increases (e.g. $14 \%$ of R\&D to sales). Afterwards there is an inverse relationship. But anyway as admitted by authors the most innovative companies have the highest ratings.

Research on the listed companies in the regional markets also was able to prove positive effect on the firms' profitability and companies' value driven to a certain extent by investments in the innovations. Analyzing listed companies in Baltics, researchers' discovered that the intangibles have a significant influence on the firm's market value emphasizing that the critical level of intangibles is $1 \%$ of total assets. In case intangibles exceed it, the value of the company significantly increases as well (Berzkalne, Zelgalve 2014).

Intangible assets appeared to be an important determinant of the Australian firm market value based on Tobin's q. Additionally, it is found that contemporaneous R\&D expenditure positively influences market value (Bosworth, Rogers 1998).

Villalonga (2004) in his research on the US listed companies argues that the greater is the intangibility of the company's resources, the more sustainable is its competitive advantage, saying that investing in intangibles is "high risk and high return strategy". Warusawitharana (2008) analyzing US listed companies concluded that there is significant economic and statistical relationship between innovation (R\&D) and profitability, which translates further in the positive influence also on the expected increase in company value.

Another study on the US companies focused on discovering the effect of R\&D investing on the firm stock performance stating that both in the manufacturing and in the service industry investments in R\&D positively influence company performance (Ehie, Olibe 2010).

Research on Iranian companies (Sahar, Yalali 2014) proved that there is a time lag of 4 years between $R \& D$ spending and future profitability.

Researching innovativeness potential of the Indonesian public companies Rika Gamayuni (2015) found that the level of intangible assets does not exert any influence on the debt policies of the companies but positively influences company value and capital profitability. 
Theoretically, the company introducing new products into the market for a certain period can enjoy premium pricing and monopoly profits (Lieberman, Montgomery 1988). Cho and Pucik (2005) found the evidence that firm's innovativeness supports growth and profitability proposing innovativeness-quality-performance model. Another study by Artz et al. (2010) supports the argument that innovations (new product announcements) have power in determining company's sales growth and profitability. Noteworthy that there was a negative relationship discovered between the patents and profitability as described by ROA and sales growth.

The vast majority of studies produced by academics are basically unanimous regarding the conclusion: investing in innovations most probably will lead to the increased profitability and company value. Innovation is usually determined by $R \& D$ spending or by new product launch or by the intangible assets level. Found relationship does not apply to the patent as innovation proxy. The present study contributes to further research of the mentioned relationship by analyzing innovation investing effect by the companies domiciled in the Central and Eastern European region.

\section{Research design}

\subsection{Determinants of innovation potential}

Innovation potential of the company can be described based on the following indicators:

1. Number of patents and patent applications is a direct measure of the company's new products, which positively correlates with $\mathrm{R} \& \mathrm{D}$ spending, are supposed to protect the innovator from the competition of the invented product replication. But not always patents are able to protect monopoly profits for a prolonged time period there was a negative correlation found between profitability and patents found (Artz et al. 2010). The problem of using number of patents is that not all patents are being monetized. Besides, a lot of innovations are not being patented (e.g. process innovations), so they do not always provide the true picture of the corporate innovativeness.

2. $R \& D$ expenditure relative to sales is most-used indicator in the studies on the innovations by the companies. It provides information on the money invested by the company to innovate, but it does not provide information about the output of the efforts, thus efficiency of the investments. The biggest obstacle of using R\&D costs in the research, its unavailability for the smaller companies, which do not report it separately.

3. A very obvious indicator of innovativeness potential is new products announcements and sales of new products launched during the last three years. It should be noted that new product announcements positively correlate with the number patents (Artz et al. 2010). The inability of obtaining good quality data on the new products announcements particularly for small companies is a major disadvantage for making research based on this indicator.

4. Intangible assets relative to total assets might be a good determinant of the innovativeness as it is rather easy to obtain data also for smaller companies. Intangibles 
often considered to be an intellectual capital of the company being comprised of the brands, trademarks, copyright, R\&D in progress, licenses etc. (Rogers 1998; Craig, Moore 2002).

However, this indicator sometimes might be misleading as some of the 'soft' assets, the value of which appear on the balance sheet, might be developed not by the company itself (e.g. bought licenses).

5. It can be argued that qualitative assessment of the innovativeness could be one of the best indicators as it assumes thoroughly conducted survey of the enterprise efforts directed to the innovating processes and products. However, due to the extensive amount of time required to conduct the survey it is not commonly used indicator in the academic and business research.

\subsection{Sample data}

The authors used company data on public and private firms extracted from Amadeus database. The focus was on the Central and Eastern European region by including Bulgaria, Croatia, Czech Republic, Estonia, Hungary, Poland, Romania, Slovakia, Slovenia, Latvia and Lithuania in the dataset. Criterion for the company inclusion was more than 100000 EUR in revenues. Initial sample consisted of 2672 companies for the period of 10 years from 2005 to 2013.

\subsection{Methodology}

Considering data availability for private companies, the authors selected intangible assets vs. total assets ratio as proxy for the innovation potential of the company. Financial performance was assessed based on the profitability ratios: return on equity, gross margin and profit margin.

Two methods were applied to determine the relationship between the intangibles and corporate performance:

1. Quartile analysis based on the intangible assets was employed. Additionally, the authors separated the sample in two groups by $1 \%$ intangible level to test the conclusions of a similar study on listed Baltic companies by Berzkalne and Zelgalve (2014). To compare the research results and to detect whether significant difference exists, the authors also have taken 3\% intangible level as the division level;

2. As the sample was large, the authors also did mean analysis by dividing it into smaller groups. Large concentration of observations was with intangibles level being below $10 \%$. Therefore, the division by $1 \%$ interval was applied to the companies reporting intangibles below $10 \%$ of total assets. If intangibles level exceeded $10 \%$, then $10 \%$ interval was applied. For each group mean profitability was calculated. The values of negative profitability were systematically excluded from the analysis due to low number of the cases leading to the inability to make statistically significant conclusions. Based on the intervals' means, the regression model (1) was ran to detect the possible relationship. 


$$
\mathrm{ROE}=\mu+\beta^{\star} \operatorname{Intg}+\varepsilon,
$$

where: Intg - intangible asset divided by total asets, average interval value; ROE - return on equity.

To better explain the relationship between the variables the authors also used polynomial equation to detect possible non-linear relationship in case intangibles make more than $10 \%$ of assets (2).

$$
\mathrm{ROE}=\mu^{\star} \operatorname{Intg}^{2}+\beta^{\star} \operatorname{Intg}+\gamma .
$$

Two more models were run taking gross profitability (GM) and net profitability (NM) as dependent variables in the Equations 1 and 2. For every case an equation for the companies having intangibles of less than $10 \%$ (interval of $1 \%$ ) and a regression for companies having intangibles of more than $10 \%$ (interval of 10\%) were analysed. Negative profitability (ROE and profit margin) cases were systematically excluded from the sample as the number of companies in the mean clusters was limited not allowing to make robust conclusions. The main statistical properties of the regressions were checked during the research.

\section{Results of the research}

\subsection{General overview}

Table 1 provides a comparative view on the level of intangibles in different regions for a certain time period. It is obvious that the figures for the companies domiciled in the less developed Central and Eastern European are significantly lower than the average intangible level reported by their Western European peers, possibly depicting their lower innovation potential.

Table 1. Average intangibles in \% of total assets

\begin{tabular}{lccccccc}
\hline \multicolumn{1}{c}{ Region } & 2013 & 2012 & 2011 & 2010 & 2009 & 2008 & 2007 \\
\hline CEE & $2.3 \%$ & $2.3 \%$ & $2.5 \%$ & $2.4 \%$ & $2.4 \%$ & $2.0 \%$ & $2.0 \%$ \\
\hline Western Europe & $11.6 \%$ & $11.4 \%$ & $11.5 \%$ & $11.3 \%$ & $11.1 \%$ & $10.6 \%$ & $10.1 \%$ \\
\hline Listed EU companies & $17.2 \%$ & $15.2 \%$ & $15.5 \%$ & $15.2 \%$ & $14.7 \%$ & $13.8 \%$ & \\
\hline Listed US companies & $19.2 \%$ & $19.4 \%$ & $18.7 \%$ & $18.2 \%$ & $18.5 \%$ & $15.7 \%$ & \\
\hline
\end{tabular}

Source: authors.

Noteworthy, that the intangible assets of the stock-exchange quoted companies are much higher than the general sample for Western Europe, which consists of both private and listed companies. Intangibles in average form almost a fifth part of the US listed companies' balance sheet, which is a bit higher than in case of Western European quoted companies.

The data in the Table 1 also points out the long-term trend of the increasing intangible assets weight in the companies' balance sheets. Regardless of the public/private status and of the location, the companies are increasing their investments in the intangibles, indicating that the knowledge- and skill-based side of the business entities is rapidly developing. 


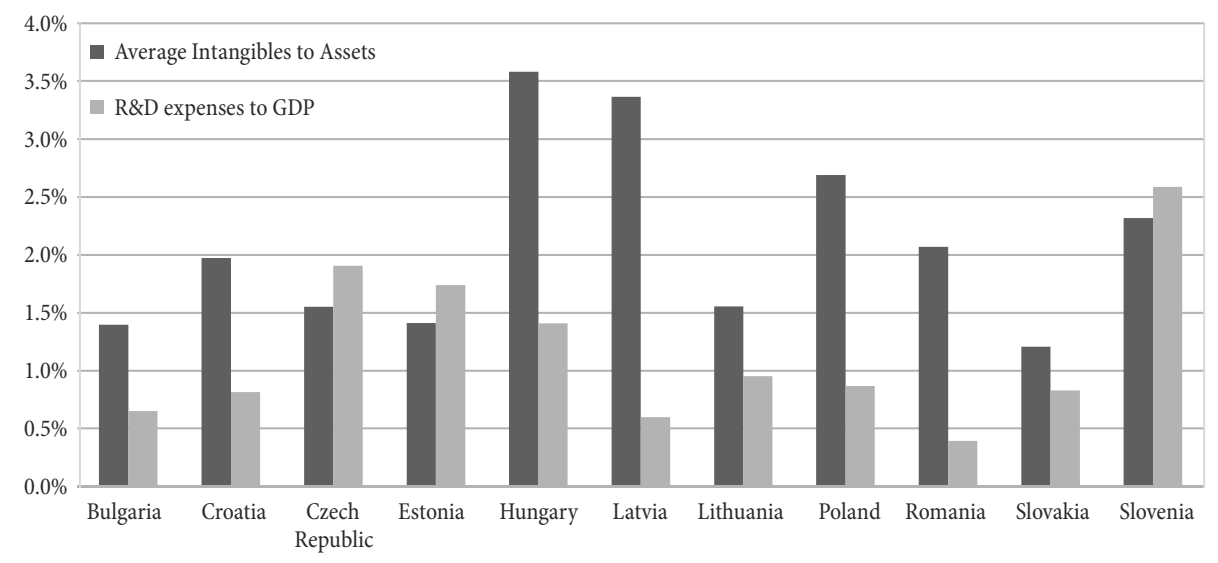

Fig. 1. Average intangibles in \% of total assets and R\&D expenses to GDP by CEE countries (Fiscal Year 2013)

Source: authors.

However, another side of the coin is that the increasing intangibility of the resources can potentially raise constraints to the investors as intangible assets often can pose a higher risk than tangible collateral (OECD 2011).

Putting the average intangible weight on the companies' balance sheet in context with the $\mathrm{R} \& \mathrm{D}$ investing by countries, it becomes surprising that Estonian companies report the lowest level of intangibles (Fig. 1). On the other hand, Latvian and Hungarian companies report the highest resource intangibility, while the countries' investment in $R \& D$ is among the lowest. This might be partially attributed to the fact that $\mathrm{R} \& \mathrm{D}$ figure includes not only private but also public investments.

\subsection{Level of intangibles and profitability - quartile analysis}

One of the simplest and most commonly used method to detect expected relationship between the two variables is to conduct the percentile analysis. The sample was divided into four equal groups by the level of intangibles and median profitability ratio was calculated for each. The first quartile consists of the companies with the highest intangible assets level, while the fourth - shows the result for the companies with the lowest intangibles relative value.

Based on the capital profitability analysis, one concludes that having low intangible portion on the balance sheet improves profitability of the business. In the majority of the observed years the companies with lower intangibles showed higher profitability.

The answer to the question on whether the companies, which invested more in the intangibles and which appear to have higher innovativeness potential, can charge premium prices to leverage on their inventions was found to be positive. Gross margin describing company's pricing ability is higher for those entities, which possess larger intangible capital.

The profit margin analysis does not provide the ground for making robust conclusions as the results plotted on the chart are mixed (Fig. 2). Interestingly, the companies classified 
into $3^{\text {rd }}$ quartile have much successfully survived financial crisis compared to the market in general.

Despite the detected possible relationship between intangible assets relative value and profitability based on ROE and gross margin, more detailed analysis is needed due to rather chaotic structure of the gathered data sample and due to the large number of companies with the intangible assets below $1 \%$. The analysis results are provided in the next section.

Besides the quartile analysis, the authors tested the profitability of the enterprises based on the intangible level as suggested by Berzkalne and Zelgalve (2014). The authors selected 2 division points $-1 \%$ and $3 \%$ intangible assets vs. total assets.

The results obtained (Fig. 3) suggest that there is no significant difference between the results divided in groups by $1 \%$ and $3 \%$ in all profitability cases.

The discrepancy in the profitability results of the companies, having intangibles below or above certain level, is rather obvious on every dimension of the profitability in majority of cases. In case of return on equity, the chart results support the quartile analysis conclusion that the lower intangibles the higher is capital profitability with exceptions in 2005 and 2006 years.

In case of gross margin, the difference is the most obvious. Higher share of intangibles in total asset structure succeeds higher gross profitability. This relationship is even more evident if comparing the results, when division of the sample is based on $3 \%$.
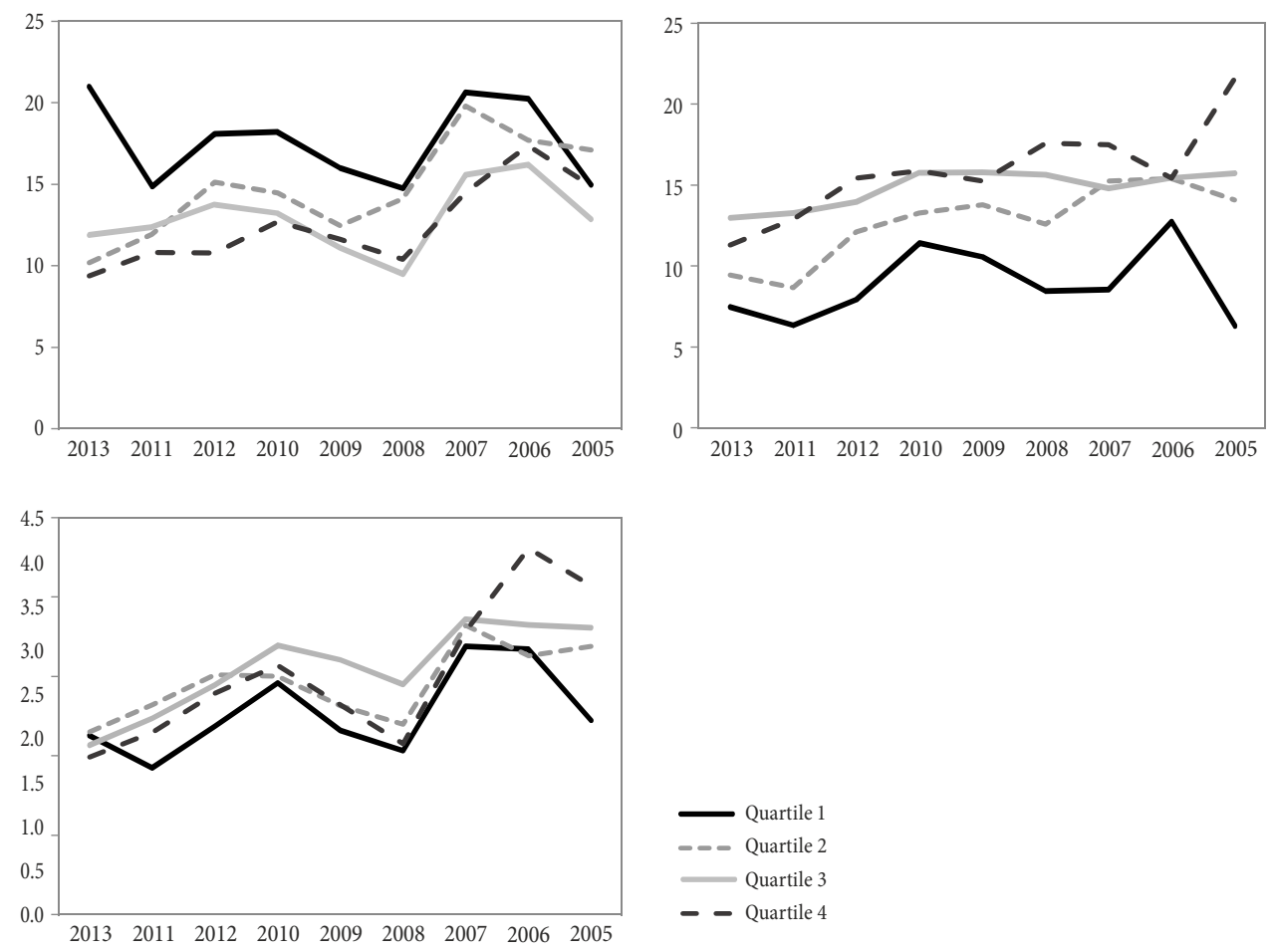

Fig. 2. Median ROE, GM and PM by Intangibles quartiles ( $1^{\text {st }}$ quartile - lowest level of intangibles) Source: authors. 

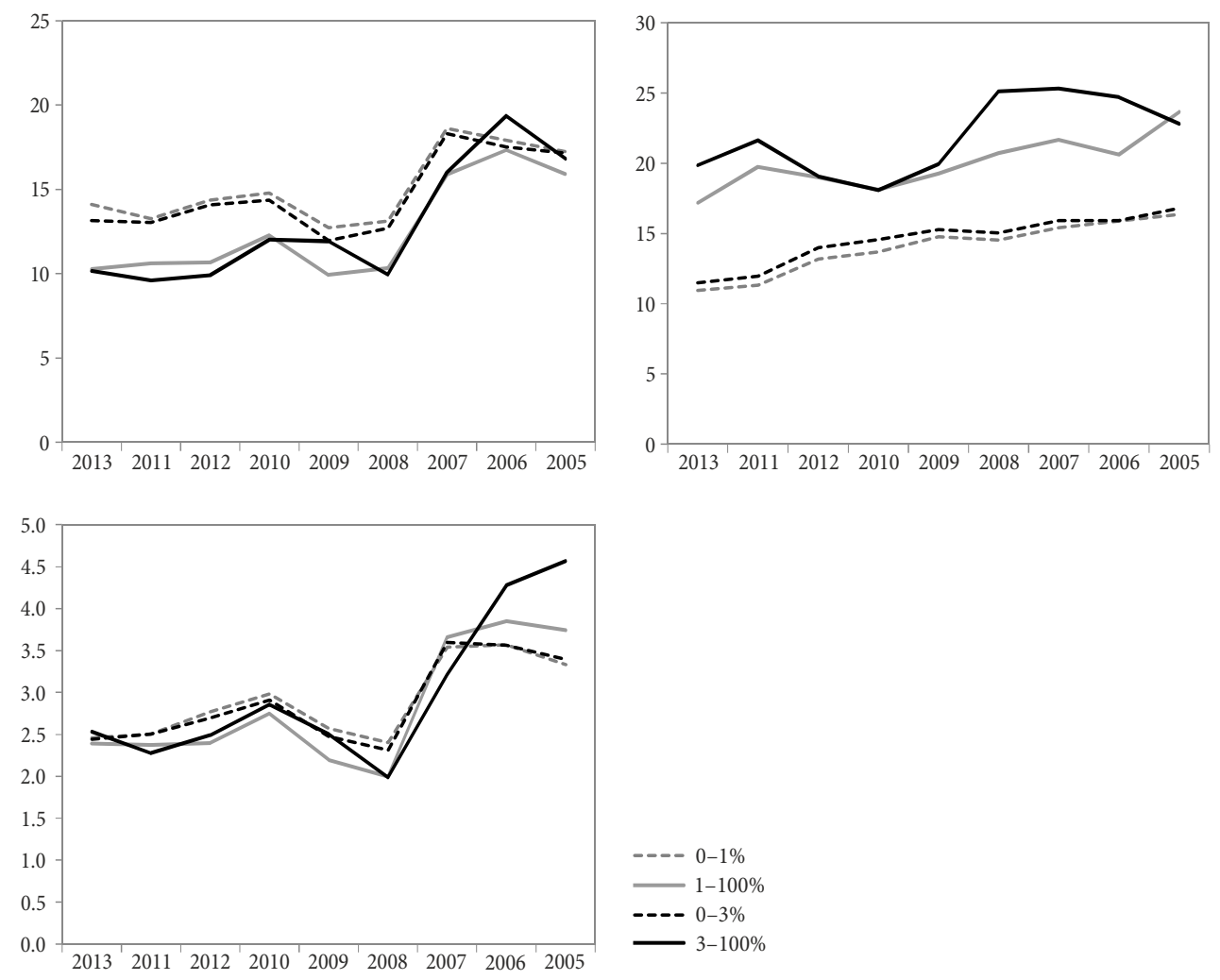

Fig. 3. Median ROE, GM and PM based on the intangibles levels Source: authors.

Similar to quartile analysis, profit margin results appear to be ambiguous, showing that after financial crisis there is no any difference in the profit margins of the companies with heavy intangible assets based and those, which do not invest in the intangibles.

\subsection{Level of intangibles and profitability - mean analysis}

More precise view on the effect created by the investment in intangible assets on the corporate financial performance is provided with the help of the mean analysis.

The analysis on ROE (Fig. 4, Table 1A) divided into two clusters of intervals show that there is 0.63 correlation between the level of intangibles and capital profitability if the intangibles make more than $10 \%$ of total assets. In case of lower intangibles level the correlation is 0.49 . However, both models are not statistically significant based on t-stat (Table 2A).

Figure 5 on gross profitability shows that basically there is no any trend for the ratios below $10 \%$ intangibles level, while there is a significant upward trend for the values above $10 \%$ (Fig. 5, Table 3A.). The analysis on the significance between the groups' means (above $10 \%$ intangibles) is statistically significant, so the companies benefit from investing in the intangible assets (Table 4A). 


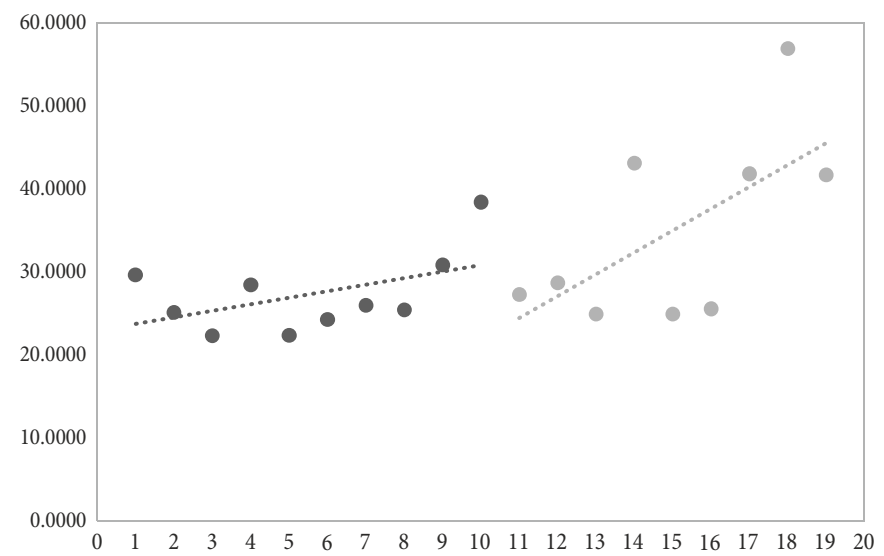

Fig. 4. Return on equity analysis: $\mathrm{x}$ axis - intangibles level groups in ascending order; $y$ axis - mean value of ROE; (polynomial regression - Fig. 1A) Source: authors.

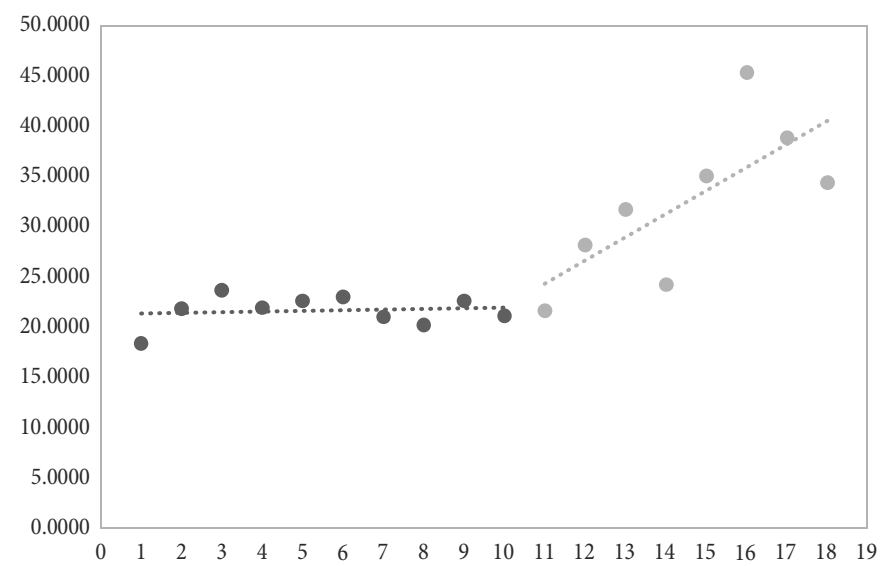

Fig. 5. Gross margin mean analysis: $\mathrm{x}$ axis - intangibles level groups in ascending order; $y$ axis - mean value of gross margin (polynomial regression - Fig. 2A) Source: authors.

Polynomial regression (Fig. 2A) provides better view on the variables' relationship as coefficient of determination is higher: 0.6 vs. 0.5 for linear regression. This is due to the declining gross profitability in case of very high intangibles.

Unlike the results obtained through the quartile analysis, there was detected relationship between the intangible assets and profit margin on the wider intervals at increased intangible assets level (Fig. 6, Table 5A). Similarly to the gross margin case, no any plausible influence from intangible assets investing on the net profitability was found on the intervals from $0 \%$ to $10 \%$. However, the analysis based on high intangible levels showed that there is a strong correlation of 0.74 between the intangibles and profitability, and the linear regression describing the relationship is statistically significant (Table 6A). 


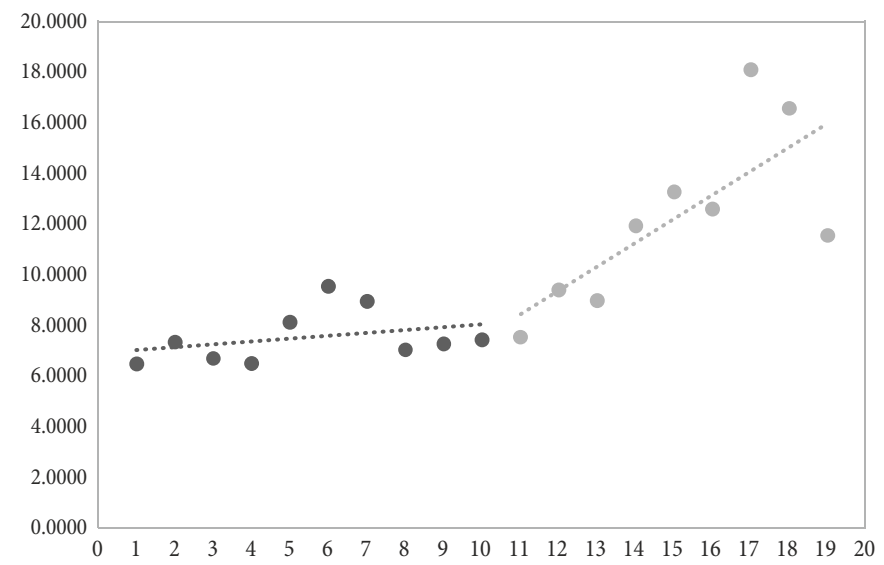

Fig. 6. Profit margin mean analysis: $\mathrm{x}$ axis - intangibles level groups in ascending order; $\mathrm{y}$ axis - mean value of profit margin; (polynomial regression - Fig. 3A)

Source: authors.

\section{Conclusions and recommendations}

Intangible assets were selected to be a proxy of the innovation potential of the private companies mainly due to their high accessibility and good quality of figures. The comparative analysis indicated that overall level of intangible assets recorded by the companies domiciled in the developed countries is much higher than that reported by their peers in less developed countries, which might point to the lower innovation potential of the latter. Stock exchange listed companies in USA and Europe in turn have higher resource intangibility reporting higher share of intangibles than the general sample. The authors have conducted quartile analysis and mean analysis, which involved assumed division in clusters.

Quartile analysis: lower intangibles are associated with higher capital profitability, meaning that they are not able to generate returns higher than the returns generated by the other fixed or current assets. So, higher innovation potential does not contribute to the higher capital profitability. The authors have noticed that there is a certain layer of the companies with high profitability and low intangible assets. Very often these companies are offshored centres of the Western European or US “mother-companies" (e.g. Continental, Nestle, Coca-Cola etc.). In this case obviously the know-how is being kept with the head entity, while the offshored centre just executes the operations. Although recently there is emerging a movement of $\mathrm{R} \& \mathrm{D}$ department relocation to the emerging markets as stated in FT article (Waldmeir 2012).

The assumption that the companies, which have higher innovation potential, can charge premium prices for temporary monopolistic product or service, cannot be rejected as the enterprises with higher level of intangibles are able to demonstrate higher gross profit margins. However, this advantage of higher earnings profitability diminishes when net profit margin is reported as there is no indication of the significant influence of the intangible assets on the net profitability. 
Dividing the sample according to the intangible level of $1 \%$ and $3 \%$, provided the base forming the same conclusions on the influence of the intangibles on the company's profitability. Besides, the results obtained did not differ based on $1 \%$ or $3 \%$ level.

Mean analysis: statistically significant relationships were found primarily for the cases when the intangible assets exceed the level of $10 \%$ in total assets. Gross margin mean analysis confirmed the conclusions made during the quartile analysis - positive correlation with intangibles. Similar conclusion was made for the net profitability. Positive intangible investment influence on the capital profitability cannot be rejected but the linear regression was not found to be statistically significant. In all profitability cases polynomial equation possesses higher explanation power as prompted by the coefficient of determination.

\section{Acknowledgements}

The paper was supported by the project 5.2.2 "The Development of Innovation and Entrepreneurship in Latvia in Compliance with the Smart Specialization Strategy" within the National Research Program 5.2 "Economic Transformation, Smart Growth, Governance and Legal Framework for the State and Society for Sustainable Development - a New Approach to the Creation of a Sustainable Learning Community (EKOSOC-LV)".

\section{References}

Artz, K. W.; Norman, P. M.; Hatfield, D. E.; Cardinal, L. B. 2010. A longitudinal study of the impact of $\mathrm{R} \& \mathrm{D}$, patents, and product innovation on firm performance, Journal of Product Innovation Management 27(5): 725-740. https://doi.org/10.1111/j.1540-5885.2010.00747.x

Barber, F.; Bistrova, J. 2015. Many CEOs aren't breakthrough innovators (and that's OK) [online], [cited 15 January 2016]. Harvard Business Review (HBR). Available from Internet: https://hbr.org/2015/09/ many-ceos-arent-breakthrough-innovators-and-thats-ok

Bilevičienè, T.; Bilevičiūtè, E.; Paražinskaitè, G. 2015. Innovative trends in human resources management, Journal of Scientific Papers Economics \& Sociology 8(4): 94-109. https://doi.org/10.14254/2071-789X.2015/8-4/7

Berzkalne, I.; Zelgalve, E. 2014. Innovation and company value: evidence from the Baltic countries, Regional formation and development studies 11(3): 39-51.

Bosworth, D.; Rogers, M. 1998. Research and development, intangible assets and the performance of large Australian companies. Melbourne Institute Working Paper No. 2/98. Melbourne Institute of Applied Economic and Social Research.

Cho, H. J.; Pucik, V. 2005. Relationship between innovativeness, quality, growth, profitability, and market value, Strategic Management Journal 26(6): 555-575. https://doi.org/10.1002/smj.461

Collins, J.; Hansen, M. T. 2011. Great by choice: uncertainty, chaos, and luck-why some thrive despite them all. Harper Business.

Craig, L.; Moore, M. 2002. Intangible assets, intellectual capital or property? It does make a difference [online], [cited 15 January 2016]. The Journal of Colorado's innovation economy. Available from Internet: http://klminc.com/branding_brand-strategy/intangible-assets-intellectual-capital-orproperty-it-does-make-a-difference

Ehie, I. C.; Olibe, K. 2010. The effect of R\&D investment on firm value: an examination of US manufacturing and service industries, International Journal of Production Economics 128(1): 127-135. https://doi.org/10.1016/j.ijpe.2010.06.005 
Gamayuni, R. R. 2015.The effect of intangible asset, financial performance and financial policies on the firm value, International Journal of Scientific and Technology Research 4(01): 202-212.

Griliches, Z. 1984. $R$ \& D, patents, and productivity. National Bureau of Economic Research. University of Chicago Press.

Grossman, G. M.; Helpman, E. 1994. Endogenous innovation in the theory of growth, Journal of Economic Perspectives 8: 23-44. https://doi.org/10.1257/jep.8.1.23

Jaruzelski, B.; Dehoff, K.; Bordia, R. 2006. The top innovators and spenders [online], [cited 15 January 2016]. Booz Allen Hamilton. Available from Internet:http://www.boozallen.com/content/dam/ boozallen/media/file/Global_Innovation_1000_2006.pdf

Jaruzelski, B.; Schwartz, K.; Staack, V. 2015. The top innovators and spenders [online], [cited 15 January 2016]. PwC. Available from Internet: http://www.strategyand.pwc.com/global/home/what-wethink/innovation1000/top-innovators-spenders

Jones, Ch. I. 1995. R\&D-based models of economic growth, Journal of Political Economy 103: 759-784. https://doi.org/10.1086/262002

Knott, A. M. 2012. The trillion-dollar R\&D fix [online], [cited 15 January 2016]. Harvard Business Review (HBR). Available from Internet: https://hbr.org/2012/05/the-trillion-dollar-rd-fix/ar

Korn, M. 2012. You call that innovation? [online], [cited 15 January 2016]. Wall Street Journal (WSJ). Available from Internet: http://www.wsj.com/articles/SB10001424052702304791704577418250902 309914

Kraft, K.; Czarnitzki, D. 2002. Measuring the impact of innovation on firm value: a new approach. ZEW Discussion Papers No. 02-73.

Lieberman, M. B.; Montgomery, D. B. 1988. First-mover advantages, Strategic Management Journal 9(S1): 41-58. https://doi.org/10.1002/smj.4250090706

Organisation for Economic Co-operation and Development (OECD). 2011. New sources of growth: intangible assets [online], [cited 15 January 2016]. OECD. Available from Internet: http://www. oecd.org/sti/inno/46349020.pdf

Rogers, M. 1998. The definition and measurement of innovation. Parkville, VIC: Melbourne Institute of Applied Economic and Social Research.

Romer, P. M. 1990. Endogenous technological change, Journal of Political Economy 98(5) II:71-102.

Sahar, M. E.; Yalali M. R. 2014. Effect of R\&D spending on firm profitability and stock market value, Management and Administrative Sciences Review 3(4).

Urbaniec, M. 2015. Towards sustainable development through ecoinnovations: drivers and barriers in Poland, Journal of Scientific Papers Economics \& Sociology 8(4): 179-190. https://doi.org/10.14254/2071-789X.2015/8-4/13

Villalonga, B. 2004. Intangible resources, Tobin's q, and sustainability of performance differences, Journal of Economic Behavior \& Organization 54(2): 205-230. https://doi.org/10.1016/j.jebo.2003.07.001

Waldmeir, P. 2012. China offers a taste of $R \& D$ to come [online], [cited 15 January 2016]. Financial Times. Available from Internet: http://www.ft.com/intl/cms/s/0/b568f34a-2d83-11e2-9988-00144feabdc0.html\#axzz40hJs83H7

Warusawitharana, M. 2008. Research and development, profits and firm value: a structural estimation. Finance and Economics Discussion Series 2008-52. Board of Governors of the Federal Reserve System. 


\section{APPENDIX}

Table 1A. ROE mean analysis: average ROE based on intangible assets intervals

\begin{tabular}{cccc}
\hline Group No. & $\mathrm{N}$ & ROE mean & Intangible assets interval \\
\hline 1.0 & 13618 & 29.5991 & $0-1 \%$ \\
\hline 2.0 & 845 & 25.0690 & $1-2 \%$ \\
\hline 3.0 & 480 & 22.2855 & $2-3 \%$ \\
\hline 4.0 & 299 & 28.4193 & $3-4 \%$ \\
\hline 5.0 & 212 & 22.3271 & $4-5 \%$ \\
\hline 6.0 & 149 & 24.2226 & $5-6 \%$ \\
\hline 7.0 & 127 & 25.9150 & $6-7 \%$ \\
\hline 8.0 & 85 & 25.4153 & $7-8 \%$ \\
\hline 9.0 & 82 & 30.7751 & $8-9 \%$ \\
\hline 10.0 & 76 & 38.3249 & $9-10 \%$ \\
\hline 11.0 & 15973 & 27.2353 & $0-10 \%$ \\
\hline 12.0 & 440 & 28.6424 & $10-20 \%$ \\
\hline 13.0 & 168 & 24.8690 & $20-30 \%$ \\
\hline 14.0 & 80 & 43.0571 & $30-40 \%$ \\
\hline 15.0 & 42 & 24.8762 & $40-50 \%$ \\
\hline 16.0 & 22 & 25.4995 & $50-60 \%$ \\
\hline 17.0 & 18 & 41.7644 & $60-70 \%$ \\
\hline 18.0 & 3 & 56.8167 & $70-80 \%$ \\
\hline 19.0 & 2 & 41.6200 & $80-90 \%$ \\
\hline & & &
\end{tabular}

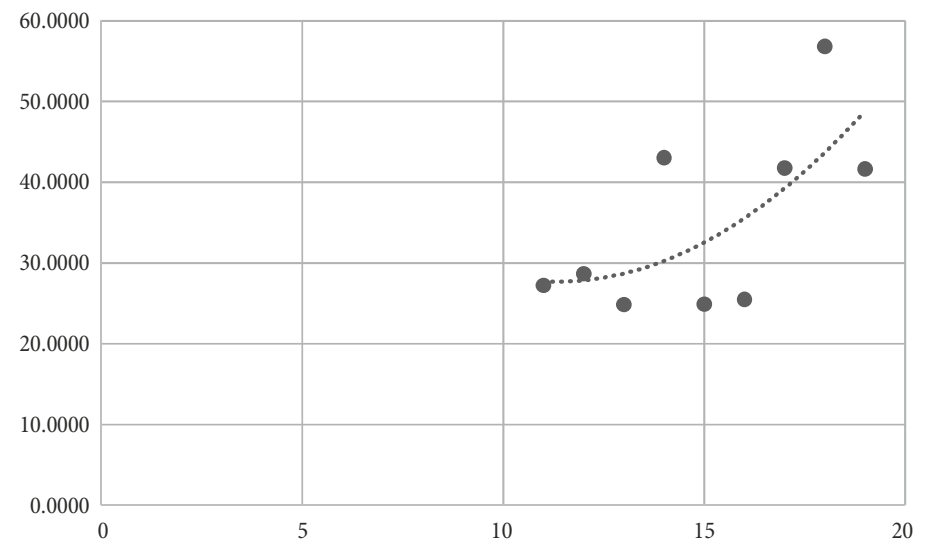

Fig.1A. Graphical representation of mean ROE by intangible assets intervals (polynomial equation) 
Table 2A. Regression statistics of ROE mean analysis

\begin{tabular}{llcc}
\hline \multicolumn{1}{c}{ Regression type } & \multicolumn{1}{c}{ Indicator } & $1 \%$ interval & $10 \%$ interval \\
\hline Linear regression & Multiple R & 0.49 & 0.63 \\
\cline { 2 - 4 } & R square & 0.24 & 0.40 \\
\cline { 2 - 4 } & Intercept (t-stat sig.) & $23.34(0.00)$ & $23.06(0.00)$ \\
\cline { 2 - 4 } & Coefficient (t-stat sig.) & $77.88(0.15)$ & $26.38(0.06)$ \\
\hline Polynomial regression & R square & & 0.45 \\
\hline
\end{tabular}

Table 3A. Gross margin mean analysis: average gross margin based on intangible assets intervals

\begin{tabular}{cccc}
\hline Group No. & $\mathrm{N}$ & Gross margin mean & Intangible assets interval \\
\hline 1.0 & 2156.0000 & 18.3188 & $0-1 \%$ \\
\hline 2.0 & 699.0000 & 21.7886 & $1-2 \%$ \\
\hline 3.0 & 228.0000 & 23.6038 & $2-3 \%$ \\
\hline 4.0 & 164.0000 & 21.8726 & $3-4 \%$ \\
\hline 5.0 & 91.0000 & 22.5465 & $4-5 \%$ \\
\hline 6.0 & 71.0000 & 22.9575 & $5-6 \%$ \\
\hline 7.0 & 56.0000 & 20.9779 & $6-7 \%$ \\
\hline 8.0 & 41.0000 & 20.1300 & $7-8 \%$ \\
\hline 9.0 & 39.0000 & 22.5521 & $8-9 \%$ \\
\hline 10.0 & 30.0000 & 21.0447 & $9-10 \%$ \\
\hline 11.0 & 3575.0000 & 21.5792 & $0-10 \%$ \\
\hline 12.0 & 175.0000 & 28.0958 & $10-20 \%$ \\
\hline 13.0 & 76.0000 & 31.6482 & $20-30 \%$ \\
\hline 14.0 & 36.0000 & 24.1600 & $30-40 \%$ \\
\hline 15.0 & 22.0000 & 34.9541 & $40-50 \%$ \\
\hline 16.0 & 22.0000 & 45.2482 & $50-60 \%$ \\
\hline 17.0 & 11.0000 & 38.7618 & $60-70 \%$ \\
\hline 18.0 & 7.0000 & 34.2943 & $70-80 \%$ \\
\hline
\end{tabular}

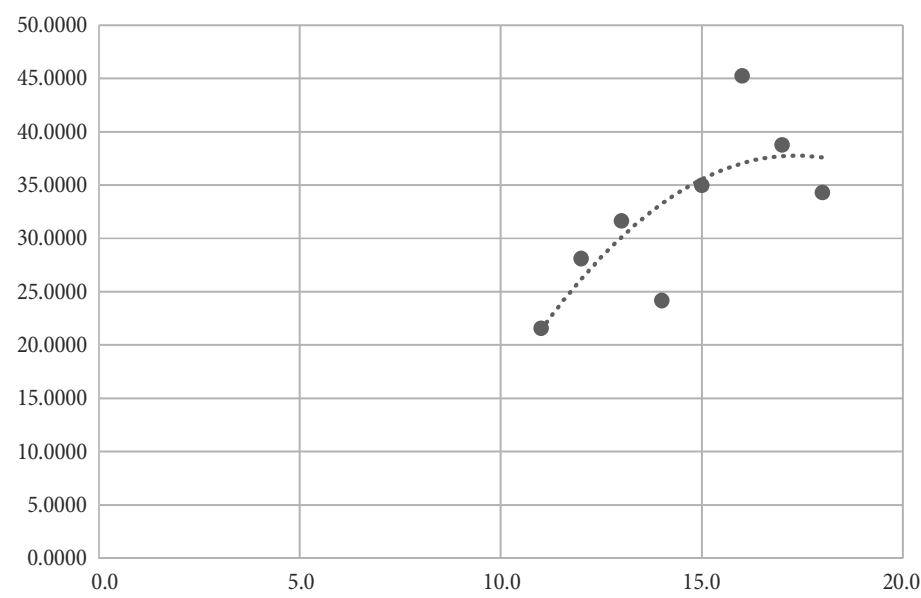

Fig. 2A. Graphical representation of mean gross margin by intangible assets intervals (polynomial equation) 
Table 4A. Regression statistics of gross margin mean analysis

\begin{tabular}{llcc}
\hline Regression type & \multicolumn{1}{c}{ Indicator } & $1 \%$ interval & $10 \%$ interval \\
\hline Linear regression & Multiple R & 0.12 & 0.73 \\
\cline { 2 - 4 } & R square & 0.01 & 0.53 \\
\cline { 2 - 4 } & Intercept (t-stat sig.) & $21.27(0.00)$ & $23.11(0.00)$ \\
\cline { 2 - 4 } & Coefficient (t-stat sig.) & $6.20(0.74)$ & $23.09(0.04)$ \\
\hline Polynomial regression & R square & & 0.60 \\
\hline
\end{tabular}

Table 5A. Profit margin mean analysis: average profit margin based on intangible assets intervals

\begin{tabular}{cccc}
\hline Group No. & $\mathrm{N}$ & Profit margin mean & Intangible assets Interval \\
\hline 1.0 & 13725 & 6.4615 & $0-1 \%$ \\
\hline 2.0 & 853 & 7.3212 & $1-2 \%$ \\
\hline 3.0 & 484 & 6.6738 & $2-3 \%$ \\
\hline 4.0 & 301 & 6.4898 & $3-4 \%$ \\
\hline 5.0 & 213 & 8.1076 & $4-5 \%$ \\
\hline 6.0 & 150 & 9.5148 & $5-6 \%$ \\
\hline 7.0 & 129 & 8.9343 & $6-7 \%$ \\
\hline 8.0 & 87 & 7.0210 & $7-8 \%$ \\
\hline 9.0 & 83 & 7.2496 & $8-9 \%$ \\
\hline 10.0 & 75 & 7.4153 & $9-10 \%$ \\
\hline 11.0 & 16100 & 7.5189 & $0-10 \%$ \\
\hline 12.0 & 448 & 9.3836 & $10-20 \%$ \\
\hline 13.0 & 173 & 8.9539 & $20-30 \%$ \\
\hline 14.0 & 79 & 11.9161 & $30-40 \%$ \\
\hline 15.0 & 41 & 13.2473 & $40-50 \%$ \\
\hline 16.0 & 25 & 12.5716 & $50-60 \%$ \\
\hline 17.0 & 17 & 18.0641 & $60-70 \%$ \\
\hline 18.0 & 4 & 16.5475 & $70-80 \%$ \\
\hline 19.0 & 5 & 11.5300 & $80-90 \%$ \\
\hline
\end{tabular}

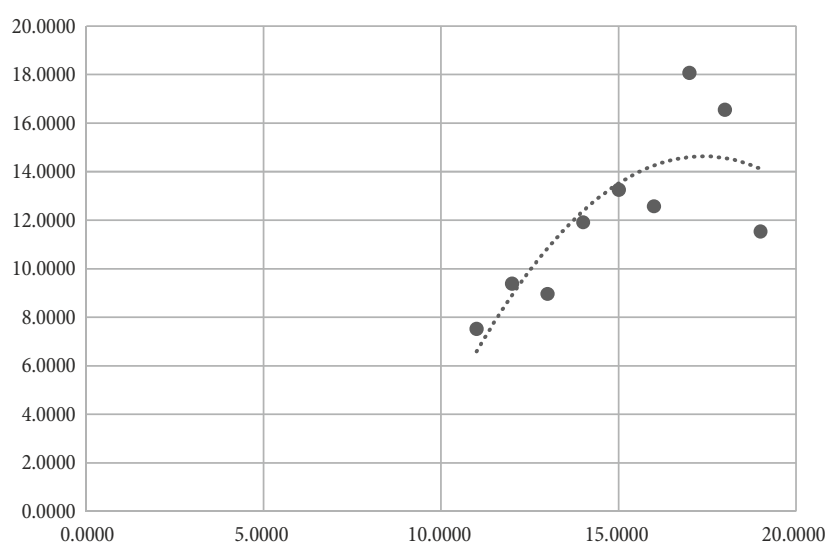

Fig. 3A. Graphical representation of mean profit margin by intangible assets intervals (polynomial equation) 
Table 6A. Regression statistics of profit margin analysis

\begin{tabular}{llcc}
\hline \multicolumn{1}{c}{ Regression type } & \multicolumn{1}{c}{ Indicator } & $1 \%$ interval & $10 \%$ interval \\
\hline Linear regression & Multiple R & 0.33 & 0.74 \\
\cline { 2 - 4 } & R square & 0.11 & 0.56 \\
\cline { 2 - 4 } & Intercept (t-stat sig.) & $6.95(0.00)$ & $7.96(0.00)$ \\
\cline { 2 - 4 } & Coefficient (t-stat sig.) & $11.25(0.35)$ & $9.40(0.02)$ \\
\hline Polynomial regression & R square & & 0.68 \\
\hline
\end{tabular}

Julija BISTROVA, Dr. oec., is an Assistant Professor at Riga Technical University. She also works for CE Services SIA, an outsourced research and financial analysis arm of Swiss asset management company CE Asset Management, as a FINANCIAL ANALYST, being a team leader in research department. Her research interests cover earnings plausibility, factors influencing stock performance in CEE markets, corporate governance, and shareholder theory.

Natalja LACE is a Professor at Riga Technical University (RTU). She graduated from RTU (former Riga Polytechnic Institute), Faculty of Engineering Economics in 1982 with the diploma of engineer-economist. The doctoral thesis (1990) was focused on alternative choice of engineering decision making. Her pedagogic activities encompass bachelor, master and doctoral programs: lecturing, supervising and reviewing bachelor, master and $\mathrm{PhD}$ theses. Natalja Lace is the Head of the Department of Corporate Finance and Economics and the Director of Master study program "Business Finance" at Riga Technical University Faculty of Engineering Economics and Management. She is a Member of the Editorial Board of several academic journals and an expert of the Latvian Council of Science. Professor Natalja Lace is an author, co-author and editor of more than 200 scientific papers and books. She is the scientific leader of research projects sponsored by the Latvian Government and Scientific Council of Republic of Latvia. Her research interests are focused on critical success factors of small and medium sized enterprises, innovation, financial literacy as well as financial aspects of business.

Rima TAMOŠIŪNIENĖ is a Professor at the Financial Engineering Department of the Vilnius Gediminas Technical University (VGTU), Lithuania. She also is a Professor at Economics Institute of Mykolas Romeris University. She graduated from VGTU (former Vilnius Civil Engineering Institute), Faculty of Civil Engineering Economics in 1982 with the diploma of engineer-economist. The doctoral thesis (1999) was focused on business project evaluation and management problems. Her pedagogic activities encompass bachelor, master and doctoral programs: lecturing such courses like Business projects management, Financial engineering, Fundamentals of financial decisions; supervising and reviewing bachelor, master and $\mathrm{PhD}$ theses. She is a Member of the Editorial Board of several scientific journals, Editor-in-Chief of scientific journal "Intellectual Economics" and an international expert of the Latvian Council of Science. Rima Tamošiunniene is an author, co-author of more than 100 scientific papers and books. Her research interests are focused on business projects and project portfolio evaluation and management, risk management, socially responsible business evaluation, assessment of intellectual capital, investment management.

Konstantins KOZLOVSKIS, Dr. oec., is an Assistant Professor at Riga Technical University. He studied at the Riga Technical University, where he became interested in financial markets and investment management. Since then, he has more than 10-year experience in trading different financial instruments, building and managing investment portfolios. The main field of research is related to financial market analysis, investment management, portfolio building and data analysis. 